\title{
Efficacy and Safety of Topical Adenosine for Androgenetic Alopecia in Adults: A Systematic Review
}

\author{
Blythe N. Ke, ${ }^{1}$ Juan Paolo David S. Villena ${ }^{1}$ and Ma. Lorna F. Frez ${ }^{2}$ \\ ${ }^{1}$ Department of Dermatology, Philippine General Hospital, University of the Philippines Manila \\ ${ }^{2}$ Department of Dermatology, College of Medicine and Philippine General Hospital, University of the Philippines Manila
}

\begin{abstract}
Background. Androgenetic alopecia (AGA), also known as pattern hair loss, is the most common type of hair loss in men and women. Due to very limited therapeutic options, search for other effective and safe drugs is necessary.

Objectives. This review aims to evaluate the efficacy and safety of a potential treatment option, topical adenosine, for AGA in male and female adults.

Methods. A search of databases (Cochrane Library, Pubmed Medline, and others) was performed with no time limitations placed. We included human interventional studies published in English involving the use of topical adenosine for AGA in healthy adult males and females. Risk bias assessment was performed using the Cochrane Collaboration criteria.
\end{abstract}

Results. All four trials in this review, with a total of 260 participants, used $0.75 \%$ topical adenosine lotion twice a day for a period of 6-12 months. Comparators were placebo, topical niacinamide, and topical minoxidil. Evaluated parameters include improvement in baldness grading as assessed by dermatologists and investigators, improvement and satisfaction as assessed by participants, anagen growth, thick/thin/vellus hair ratio, and hair density. Two trials found significant improvement with thick hair ratio $(>60$ or $>80 \mu \mathrm{m})$ with the use of topical adenosine while two trials showed higher overall participant satisfaction with topical adenosine. Few to no adverse effects were reported with its use.

Conclusion. This is the first systematic review involving topical adenosine for AGA. Topical adenosine may be effective in increasing thick hair ratio and improving the self-perception of hair growth. With minimal to no adverse effects, it may serve as an adjunct or alternative to present treatment options. However, more studies are needed to strengthen these findings.

Key Words: androgenetic alopecia, pattern baldness, baldness, topical adenosine

\section{INTRODUCTION}

Androgenetic alopecia (AGA), also known as pattern hair loss, is the most common type of hair loss in men and women. Male pattern hair loss (MPHL) appears as temporal and vertex balding while female pattern hair

Oral presentation at the $19^{\text {th }}$ Dubai World Dermatology and Laser Conference \& Exhibition, March 18-20, 2019, Dubai, United Arab Emirates.

E-Poster presented at the $41^{\text {st }}$ Annual Convention of the Philippine Dermatological Society, November 7-9, 2018, Edsa Shangri-La, Mandaluyong City, Philippines.

Corresponding author: Blythe N. Ke, MD, MBA

Department of Dermatology

Philippine General Hospital

University of the Philippines Manila

Taft Avenue, Manila 1000, Philippines

Email: blythe_ke@yahoo.com loss (FPHL) is usually described as mid frontal scalp hair thinning. This disease is familial with a polygenic mode of inheritance. ${ }^{1}$

Currently, there are only two FDA-approved medications for AGA: topical minoxidil and oral finasteride. Minoxidil, however, has adverse effects such as contact dermatitis found in $1.9-5.7 \%$ of participants in a phase III trial, ${ }^{2}$ as well as facial hypertrichosis, and irritation from propylene glycol. Oral finasteride - an option not approved for women-also has adverse effects (although rare) including decreased libido and erectile dysfunction. ${ }^{1}$ Other options for AGA would 
have patients resorting to wearing wigs and hairpieces or undergoing very expensive procedures such as laser and hair transplants. Hence, these options leave us with the desire to continue the search for other effective options with fewer adverse effects.

Topical adenosine is an option that may potentially improve AGA. By performing a systematic review, we aim primarily to assess the efficacy of topical adenosine in treating androgenetic alopecia, and as a secondary objective, to assess the presence of any adverse events associated with its use.

\section{MATERIALS AND METHODS}

Databases (Cochrane Library, Google Scholar, HERDIN, PROSPERO, Pubmed Medline, Science Direct, and TRIP) were searched using the keywords 'adenosine', 'topical adenosine', and 'androgenetic alopecia' with no time limitations placed. Initial screening was performed based on title and abstract and only human interventional studies using topical adenosine on AGA were included.

The following data were extracted from each study: study design, year, country, sample size, age, sex, race, severity of AGA, dose, and frequency of using topical adenosine and its comparator/placebo, duration and results of treatment, and authors' conclusion. Each study then underwent risk bias assessment using the Cochrane Collaboration criteria. ${ }^{3}$

\section{RESULTS}

There was a total of 677 results from the database search. After excluding those that did not meet our criteria as well as the duplicates, four studies remained and were included in this review (Figure 1). Oura et al. (2008) and

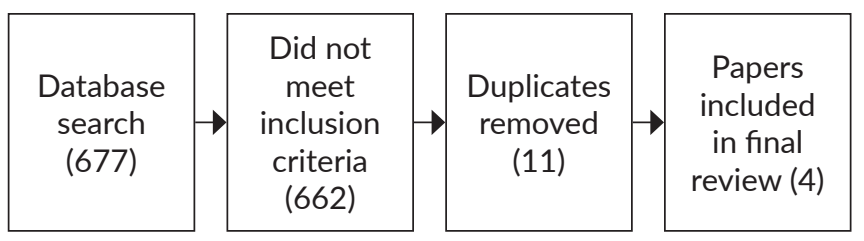

Figure 1. Database search for topical adenosine on AGA.

Iwabuchi et al. (2016) both compared topical adenosine with placebo; Watanabe et al. (2015) compared it with topical niacinamide while Faghihi et al. (2013) compared it with topical minoxidil. These studies underwent a bias risk assessment following the Cochrane Collaboration criteria (Table 1). One study had a low risk of bias, two studies had an unclear risk of bias, while another had a high risk of bias.

This review reports a total of 260 adult participants with a mean age of 38.09 years and with varying severities of androgenetic alopecia. The study population was comprised mainly of males $(n=233,89.62 \%)$ while only a small portion were females $(n=27,10.38 \%)$. The population also had a good combination of races including Japanese $(n=128)$, Caucasian $(n=38)$, and an unspecified race from an Iranian study $(\mathrm{n}=94)$. All participants had brown to black hair. Data extracted from the four studies can be found in Table 2 .

\section{Topical adenosine vs. placebo}

In a double-blind placebo-controlled study, ${ }^{4} 27$ healthy female Japanese participants applied $0.75 \%$ adenosine lotion or placebo lotion BID for 12 months. The participants had over stage 1.5 of female pattern hair loss based on a 6 -point scale. ${ }^{5}$ The efficacy was measured at the $6^{\text {th }}$ and $12^{\text {th }}$ months and this included assessment by dermatologists and investigators, hair parameters from phototrichogram, and self-assessment using a questionnaire. ${ }^{6}$

Table 1. Risk of bias assessment based on Cochrane Collaboration criteria

\begin{tabular}{|c|c|c|c|c|c|}
\hline Bias domain & Source of bias & Oura et al., 2008 & Iwabuchi et al., 2016 & Watanabe et al., 2015 & Faghihi et al. 2013 \\
\hline \multirow[t]{2}{*}{ Selection } & $\begin{array}{c}\text { Random sequence } \\
\text { generation }\end{array}$ & Yes* & Yes* & Yes & Yes* \\
\hline & Allocation concealment & Not mentioned & Not mentioned & Not mentioned & Not mentioned \\
\hline Performance & $\begin{array}{c}\text { Blinding of participants } \\
\text { and personnel }\end{array}$ & Yes & Yes & Yes & Not mentioned \\
\hline Detection & $\begin{array}{c}\text { Blinding of outcome } \\
\text { assessment }\end{array}$ & Yes & Not blinded & Yes & Yes \\
\hline Attrition & $\begin{array}{l}\text { Incomplete } \\
\text { outcome data }\end{array}$ & $\begin{array}{l}\text { Losses to follow-up } \\
\text { were disclosed; not } \\
\text { included in final analysis }\end{array}$ & $\begin{array}{c}\text { N/A } \\
\text { No drop-outs }\end{array}$ & $\begin{array}{c}\text { Losses to follow-up } \\
\text { were disclosed; not } \\
\text { included in final analysis }\end{array}$ & $\begin{array}{l}\text { Losses to follow-up } \\
\text { were disclosed; not } \\
\text { included in final analysis }\end{array}$ \\
\hline Reporting & Selective reporting & $\begin{array}{c}\text { All prespecified } \\
\text { outcomes were reported }\end{array}$ & $\begin{array}{c}\text { All prespecified } \\
\text { outcomes were reported }\end{array}$ & $\begin{array}{c}\text { All prespecified } \\
\text { outcomes were reported }\end{array}$ & $\begin{array}{c}\text { All prespecified } \\
\text { outcomes were reported }\end{array}$ \\
\hline Others & Other sources of bias & None & $\begin{array}{l}\text { Funded by adenosine } \\
\text { manufacturer }\end{array}$ & $\begin{array}{l}\text { Significant differences } \\
\text { in vellus-like hair ratio } \\
\text { and thick hair ratio at } \\
\text { baseline; funded by } \\
\text { adenosine manufacturer }\end{array}$ & $\begin{array}{l}\text { Those with allergic } \\
\text { reactions or severe } \\
\text { complications** } \\
\text { were excluded }\end{array}$ \\
\hline Judgment & - & Low risk & Unclear risk & Unclear risk & High risk \\
\hline
\end{tabular}

* Not described in detail

** Hypertrichosis or extensive hair loss 
Topical Adenosine for Androgenetic Alopecia

Table 2. Studies on topical adenosine for androgenetic alopecia

\begin{tabular}{|c|c|c|c|c|c|c|}
\hline $\begin{array}{c}\text { Author, Country, } \\
\text { Year }\end{array}$ & Study Design & $\begin{array}{l}\text { Ave. age/ } \\
\text { Sex/Race }\end{array}$ & Exclusion criteria & $\begin{array}{l}\text { Dose, frequency, } \\
\text { duration }\end{array}$ & Treatment groups & $\begin{array}{c}\text { Type and } \\
\text { Severity of AGA }\end{array}$ \\
\hline \multicolumn{7}{|c|}{ Adenosine vs. Placebo } \\
\hline $\begin{array}{l}\text { Oura et al., Japan, } \\
2008\end{array}$ & $\begin{array}{l}\text { Double-blind } \\
\text { placebo- } \\
\text { controlled RCT }\end{array}$ & $\begin{array}{l}38.9 \text { yo/ } \\
\text { Japanese F }\end{array}$ & No systemic illness & $3 \mathrm{ml} \mathrm{BID} \times 12$ mos. & $\begin{array}{l}0.75 \% \text { adenosine } \\
\text { lotion (13) } \\
\text { vs. } \\
\text { Placebo lotion (14) }\end{array}$ & $\begin{array}{l}\text { FPHL over stage } \\
1.5 \text { (Tajima's } \\
\text { classification) }\end{array}$ \\
\hline
\end{tabular}

\begin{tabular}{|c|c|c|c|c|c|c|}
\hline $\begin{array}{l}\text { Iwabuchi et al., } \\
\text { Japan, } 2016\end{array}$ & $\begin{array}{l}\text { Single-blind } \\
\text { placebo- } \\
\text { controlled RCT }\end{array}$ & $\begin{array}{l}41.5 \text { yo/ } \\
\text { Caucasian/ } \\
\text { M (brown to } \\
\text { black hair, } \\
\text { no blonde) }\end{array}$ & $\begin{array}{l}\text { No systemic illness } \\
\text { No minoxidil in past } 6 \\
\text { months }\end{array}$ & $3 \mathrm{ml} \mathrm{BID} \times 6$ mos. & $\begin{array}{l}0.75 \% \text { adenosine } \\
\text { lotion (19) } \\
\text { vs. } \\
\text { Placebo lotion (19) }\end{array}$ & $\begin{array}{l}\text { Baldness grade } \\
6 \text { (Ishino's } \\
\text { classification) }\end{array}$ \\
\hline
\end{tabular}

\begin{tabular}{|c|c|c|c|c|c|c|}
\hline \multicolumn{7}{|c|}{ Adenosine vs. Niacinamide } \\
\hline $\begin{array}{l}\text { Watanabe et al., } \\
\text { Japan, } 2015\end{array}$ & $\begin{array}{l}\text { Double-blind } \\
\text { randomized } \\
\text { study (with } \\
\text { placebo-like } \\
\text { control) }\end{array}$ & $\begin{array}{l}41.5 \text { yo/ } \\
\text { Japanese/ } \\
\text { M (all close to } \\
\text { black hair) }\end{array}$ & $\begin{array}{l}\text { No systemic illness } \\
\text { No hair dye }\end{array}$ & $3 \mathrm{ml} \mathrm{BID} \times 6$ mos. & $\begin{array}{l}0.75 \% \text { adenosine } \\
\text { lotion (51) } \\
\text { vs. } \\
0.1 \% \text { niacinamide } \\
\text { (placebo-like) } \\
\text { lotion (50) }\end{array}$ & $\begin{array}{l}\text { Pattern II or } \\
\text { IV hair loss, } \\
\text { medium (Ogata's } \\
\text { classification) }\end{array}$ \\
\hline
\end{tabular}

\begin{tabular}{|c|c|c|c|c|c|c|}
\hline \multicolumn{7}{|c|}{ Adenosine vs. Minoxidil } \\
\hline $\begin{array}{l}\text { Faghihi et al., } \\
\text { Iran, } 2013\end{array}$ & $\begin{array}{l}\text { Randomized } \\
\text { prospective }\end{array}$ & $\begin{array}{l}30.46 \text { yo/ } \\
\text { Race not } \\
\text { specified/M }\end{array}$ & $\begin{array}{l}<18 \text { yo } \\
\text { No inflammation or } \\
\text { infection of scalp } \\
\text { No hypersensitivity to } \\
\text { minoxidil/adenosine } \\
\text { No HTN, CVD }\end{array}$ & $1 \mathrm{ml} \mathrm{BID}$ x 6 mos. & $\begin{array}{l}0.75 \% \text { adenosine } \\
\text { lotion (53) } \\
\text { vs. } \\
5 \% \text { Minoxidil ( } 41 \text { ) }\end{array}$ & $\begin{array}{l}\text { MPHL grade II } \\
\text { to V (Hamilton- } \\
\text { Norwood } \\
\text { clinical scale) }\end{array}$ \\
\hline
\end{tabular}

\footnotetext{
${ }^{*}$ Significant $p<0.05$
} 


\section{At the $6^{\text {th }}$ month}

Dermatologists' assessment:

- All 'improvement' cases: $39 \%$ vs. $21 \%, p=0.4197$

Investigators' assessment:

- All 'improvement' cases: $23 \%$ vs. $29 \%, p=1.000$

Phototrichogram:

- Significant improvement with anagen hair growth rate and thick hair (>80 $\mu \mathrm{m})$ ratio

Self-assessment:

- Change in appearance $p=0.148$

- Change in hair growth $p=0.041^{*}$

- Prevention of hair loss $p=0.017^{*}$

\section{At the $12^{\text {th }}$ month}

Dermatologists' assessment

- All 'improvement' cases: $85 \%$ vs. $36 \%, p=0.0183$ *

Investigators' assessment:

- All 'improvement' cases: $62 \%$ vs. $36 \%, p=0.2568$

Phototrichogram:

- Significant improvement with anagen hair growth rate and thick hair $(>80 \mu \mathrm{m})$ ratio

Self-assessment:

- Change in appearance $p=0.048^{*}$

- Change in hair growth $p=0.081$

- Prevention of hair loss $p=0.036^{*}$

No adverse effects

Dermatologists' assessment:

- Change in baldness grade: -0.35 vs. $0.179, p=0.3955$

Phototrichogram:

- Change in hair density: 4.9 vs. $-3.8 p=0.04^{*}$

- Change in thick hair $(>60 \mu \mathrm{m})$ proportion: 5.5 vs. $-8.5, p=0.0001^{*}$

- Change in thin $(40-60 \mu \mathrm{m})$ hair proportion: -4.1 vs. $1.9, p=0.1113$

- Change in vellus $(<40 \mu \mathrm{m})$ hair proportion: -1.4 vs. $6.6, p=0.0154^{*}$

No adverse effects
Compared to placebo, topical adenosine showed significant improvement via dermatologists', investigators', and self-assessments.

Topical adenosine stimulates hair growth and increases thicker hairs.
Dermatologists' assessment:

- All "improvement cases" in baldness grade: 48 vs. $38, p=0.0124^{*}$

Phototrichogram:

- Change in thick hair $(>60 \mu \mathrm{m})$ ratio: 10.4 vs. $6.1, p=0.0331^{*}$

- Change in thick hair $(>80 \mu \mathrm{m})$ ratio: 5.1 vs. $2.5, p=0.0268$

- Change in vellus hair $(<40 \mu \mathrm{m})$ ratio: -7.2 vs. $-5.9, p=0.5364$

- Rate of change in hair density: 2.7 vs. $1 \mathrm{p}=0.3789$

Self-assessment:

- Thickness of hair: 24 vs. $10, p=0.0137^{*}$

- Overall thickness of hair: 30 vs. $25, p=0.5375$

Adverse effects of adenosine: seborrhea and scaling but not causal
Topical adenosine is effective increasing proportion of thick hairs and may be used as an alternative to minoxidil.
Hair recovery:

- Complete recovery: 0 vs. 0

- Relative recovery: 1 vs. $1, p=0.99$

Patient satisfaction:

- Satisfied: 37 vs. $13, p=0.003^{*}$

- No change: 16 vs. 22

- Not satisfied: 0 vs. 6

Adverse effects of adenosine: folliculitis and pruritus
Topical adenosine increases thick hair ratio and is not associated with significant adverse events. 
Results showed no significant changes between the adenosine group and placebo group at the $6^{\text {th }}$ month in terms of the dermatologists' (39\% vs. $21 \%, \mathrm{p}=0.4197$ ) and investigators' assessments ( $23 \%$ vs. $29 \%, \mathrm{p}=1.0000)$. In the $12^{\text {th }}$ month, however, significant improvements were seen with the dermatologists' assessment ( $85 \%$ vs. $36 \%, \mathrm{p}=0.0183$ ) but not with the investigators' assessments (62\% vs. $36 \%$, $\mathrm{p}=0.2568){ }^{4}$

Based on the graphs presented by the authors, anagen hair growth rate and thick hair $(>80 \mu \mathrm{m})$ ratio showed significant improvement in the $6^{\text {th }}$ and $12^{\text {th }}$ months. Other parameters such as anagen hair ratio, thin hair $(<40 \mu \mathrm{m})$ ratio, and hair density did not show significant improvement at either $6^{\text {th }}$ or $12^{\text {th }}$ month. ${ }^{4}$

In terms of self-assessment, participants were satisfied with the prevention of hair loss at both assessment periods. Significant improvement with hair growth at six months $(p=0.041)$ and with the appearance of hair at 12 months $(\mathrm{p}=0.048)$ was also perceived by participants. No adverse effects were noted during the entire study period. ${ }^{4}$ Overall, compared to placebo, adenosine showed significant improvement via dermatologists' and self-assessments. It also had a significantly positive effect on the anagen hair growth rate and thick hair ratio.

A second study, by Iwabuchi and colleagues, ${ }^{7}$ also compared $0.75 \%$ adenosine lotion with placebo in a single-blinded 6-month-study with 38 Caucasian male participants. The participants had brown to black hair and on average, presented with a baldness grade of 6 based on the Ishino scale. $^{8}$

Compared with placebo, topical adenosine showed significant improvements in terms of hair density ( 4.9 vs. -3.8 , $\mathrm{p}=0.04)$, thick hair proportion (5.5 vs. $-8.5, \mathrm{p}=0.0001)$, and vellus hair proportion (-1.4 vs. 6.6, $\mathrm{p}=0.0154)$. However, it had no advantage over placebo in improving overall baldness grade. There were also no adverse effects seen, leading the authors to conclude that adenosine may be a useful alternative to minoxidil. ${ }^{7}$

\section{Topical adenosine vs. topical niacinamide}

A double-blind randomized study was performed on healthy adult Japanese males with pattern II or IV AGA (Ogata's classification) by Watanabe and colleagues in 2015. In place of a placebo, $0.1 \%$ niacinamide lotion was compared against $0.75 \%$ adenosine lotion. After six months, there was a significantly higher number of cases showing improved baldness grade among the treatment group compared to the niacinamide group ( 48 vs. $38, p=0.0124$ ). The treatment group also showed a significant change in thick hair ratio defined as $>60 \mu \mathrm{m}$ (10.4 vs. 6.1, $\mathrm{p}=0.0331)$ and in thick hair ratio defined as $>80 \mu \mathrm{m}$ (5.1 vs. $2.5, \mathrm{p}=0.0268)$ compared to the niacinamide group. Through a questionnaire at the end of the study, participants in the treatment group reported satisfaction ( 24 vs. $10, p=0.0137)$ in terms of hair thickness; however, no significant difference was seen between the groups in terms of overall satisfaction. While this study observed adverse effects such as scaling and seborrhea, these were not directly attributed to the use of adenosine. ${ }^{9}$

\section{Topical adenosine vs. minoxidil}

In this randomized prospective study comparing topical adenosine to the current standard, topical minoxidil, adult males of the unspecified race with male pattern hair loss grade II to V (Hamilton-Norwood) were included. ${ }^{10}$ Results showed significant participant satisfaction in the adenosine group compared to the minoxidil group ( 37 vs. 13 , $\mathrm{p}=0.003$ ) due to the perceived faster prevention of hair loss and favorable appearance of newly grown hairs. There were, however, no significant changes in hair recovery. Adverse effects observed with the use of adenosine include folliculitis and pruritus. ${ }^{10}$

\section{DISCUSSION}

There are male and female patterns of AGA, with the male pattern AGA being characterized by androgen hyperactivity and genetic predisposition. Androgens bind to its receptors at the hair bulb, causing an alteration in the dermal papilla during early anagen. These alterations lead to shorter hair, smaller anagen follicles, as well as shorter and delayed anagen phase. The mode of inheritance of MPHL is polygenic with polymorphisms of different genes being linked to premature balding. These include the androgen receptor gene, $5 \alpha$ reductase gene, and two other genes found on chromosomes 3 and $21 .{ }^{1}$

Some authors assume this pathophysiologic model to be the same for females. However, others would consider FPHL to be more complex since the role of androgen in its pathogenesis has not been fully elucidated. In fact, a combination of genetic, hormonal, and environmental factors was thought to be contributory. ${ }^{11}$

Adenosine is a purine nucleoside with a mechanism of action linked to that of minoxidil. A proposed pathway by Marubayashi, Nakaya, Fukui, Li, and Arase involves the stimulation of dermal papilla cells by minoxidil, leading to the activation of the adenosine receptor signal transduction pathway. This pathway allows an increase in intracellular calcium and upregulation of vascular endothelial growth factor (VEGF). Modulation of fibroblast growth factor (FGF-7), keratinocyte growth factor (KGF), and TGF- $\beta$ are also implicated in the mechanism of action of adenosine. ${ }^{4,7}$

The database search yielded 4 trials with different risks of bias. All studies, except for one, used $3 \mathrm{ml}$ of $0.75 \%$ topical adenosine twice a day for six or 12 months, which allowed for better comparison across studies. Most of the studies lasted for 12 months except for that of Oura and colleagues who acknowledged that their shorter study period (six months) could have easily affected their results. ${ }^{4}$ Meanwhile, in the study by Watanabe and colleagues, there was an unclear reason for the ethical disapproval of placebo which 
Table 3. Significant results from different parameters across studies

\begin{tabular}{|c|c|c|c|c|c|}
\hline \multirow[b]{2}{*}{ Methods } & \multirow[b]{2}{*}{ Parameters } & $\begin{array}{l}\text { Oura } \\
\text { et al., } 2008\end{array}$ & $\begin{array}{l}\text { Iwabuchi } \\
\text { et al., } 2016\end{array}$ & $\begin{array}{l}\text { Watanabe } \\
\text { et al., } 2015\end{array}$ & Faghihi et al., 2013 \\
\hline & & $\begin{array}{l}\text { Adenosine vs. } \\
\text { Placebo } \\
3 \mathrm{ml} \text { x } 12 \mathrm{mos}\end{array}$ & $\begin{array}{c}\text { Adenosine vs. } \\
\text { Placebo } \\
3 \mathrm{ml} \mathrm{x} 6 \text { mos }\end{array}$ & $\begin{array}{l}\text { Adenosine vs. } \\
\text { Niacinamide } \\
3 \mathrm{ml} \text { x } 6 \text { mos }\end{array}$ & $\begin{array}{c}\text { Adenosine vs. } \\
\text { Minoxidil } \\
1 \mathrm{ml} \text { x } 6 \text { mos }\end{array}$ \\
\hline $\begin{array}{c}\text { Dermatologist/investigator } \\
\text { assessment }\end{array}$ & Baldness scales & $\mathrm{Y}$ & $\mathrm{N}$ & Y & $\mathrm{N}$ \\
\hline Phototrichogram & $\begin{array}{c}\text { Anagen hair growth rate } \\
\text { Hair density } \\
\text { Thick hair ratio }(>80 \mu \mathrm{m}) \\
\text { Thick hair ratio }(>60 \mu \mathrm{m}) \\
\text { Thin hair ratio }(40-60 \mu \mathrm{m}) \\
\text { Vellus hair ratio }(<40 \mu \mathrm{m})\end{array}$ & $\begin{array}{l}\mathrm{Y} \\
\mathrm{N} \\
\mathrm{Y} \\
- \\
- \\
\mathrm{N}\end{array}$ & $\begin{array}{l}- \\
\mathrm{Y} \\
- \\
\mathrm{Y} \\
\mathrm{N} \\
\mathrm{Y}\end{array}$ & $\begin{array}{l}- \\
N \\
Y \\
Y \\
- \\
N\end{array}$ & $\begin{array}{l}- \\
- \\
- \\
- \\
- \\
-\end{array}$ \\
\hline Self-assessment questionnaire & Overall satisfaction & $\mathrm{Y}$ & - & $\mathrm{N}$ & $\mathrm{Y}$ \\
\hline Adverse effects of adenosine & Adverse effects of adenosine & None & None & Seborrhea, scaling & Pruritus, folliculitis \\
\hline
\end{tabular}

$Y$ - Yes. Significant changes were observed between topical adenosine and comparator.

$N$ - No. No significant changes were observed between topical adenosine and comparator.

Dash (-) - Parameter was not tested in the study.

compelled the authors to use topical niacinamide instead. ${ }^{9}$ Niacinamide, an antioxidant and inflammatory agent, affects hair growth indirectly. It converts to nicotinamide adenine dinucleotide (NAD) which fuels rapidly proliferating tissues such as the hair follicle. ${ }^{12}$

The studies measured efficacy and safety parameters using different methods. Nevertheless, results across the studies are analyzed and presented in Table 3. Two out of four studies showed significant improvement via grading scales by dermatologists or investigators and thus makes for an equivocal result in terms of improvement in baldness grades. On the other hand, three studies measured improvements in thick hair proportion $(>60$ or $>80 \mu \mathrm{m})$ and all found significant improvements in the adenosine group compared to placebo and niacinamide.

With regard to self-assessment, the different questionnaires used made cohesive analysis challenging. Two out of three studies showed significant overall improvement via self-assessment, specifically with the perception of hair thickness, new growth, and prevention of hair loss. Furthermore, the few adverse effects reported in two of the studies which included seborrhea, scaling, pruritus, and folliculitis, showed that adenosine may be a safe treatment option for AGA.

Topical adenosine is not widely available in the Philippines. It is, nonetheless, marketed as a shampoo and scalp treatment under a Japanese cosmetic brand and costs higher than the minoxidil solution. Despite these issues with cost and availability, topical adenosine may still be a treatment option for AGA due to its few adverse effects.

\section{Strengths}

This is the first systematic review on the use of topical adenosine for patients with AGA. The studies included both Asian and Caucasian participants which can allow us to perceive any existing difference in the response to medication.
The studies also used the same concentration of adenosine, permitting a more uniform interstudy comparison. In addition, the use of both subjective and objective parameters provides a more holistic assessment of the efficacy and safety of adenosine.

\section{Limitations}

There are few studies available and among the participants, only $10 \%$ were females. Some of the studies had shorter follow-up periods as well as different dosages and frequency than others. The limited availability and higher cost of adenosine may also be a factor in the number of existing trials.

\section{CONCLUSION}

The use of topical adenosine may increase the thick hair ratio and improve the self-perception of hair growth. It has few to no adverse effects and may serve as an adjunct or alternative to minoxidil. With the limited yield from the database search, more trials are required with a higher number of female participants. In addition, the dose, frequency, and duration of the effect of adenosine have yet to be established or identified. A minimum follow-up period of six months should most likely be used to observe if therapeutic effects will be sustained.

\section{Statement of Authorship}

All authors participated in data collection and analysis, and approved the final version submitted.

\section{Author Disclosure}

All authors declared no conflicts of interest.

\section{Funding Source}

This paper was funded by the authors. 


\section{REFERENCES}

1. Perera E, Sinclair R. Chapter 11: Androgenetic Alopecia. In: Scalp and its disorders. Jaypee Publishing; 2015.

2. Friedman ES, Friedman PM, Cohen DE, Washenik K. Allergic contact dermatitis to topical minoxidil solution: etiology and treatment. J Am Acad Dermatol. 2002; 46(2):309-12.

3. Cochrane. Assessing Risk of Bias in Included Studies [Internet]. Cochrane Methods Bias. 2018 [cited 2018 Sep 1]. Available from: / bias/assessing-risk-bias-included-studies

4. Oura H, Iino M, Nakazawa Y, Tajima M, Ideta R, Nakaya Y, et al. Adenosine increases anagen hair growth and thick hairs in Japanese women with female pattern hair loss: a pilot, double-blind, randomized, placebo-controlled trial. J Dermatol. 2008; 35(12):763-7.

5. Tajima M, Hamada C, Arai T, Miyazawa M, Shibata R, Ishino A. Characteristic features of Japanese women's hair with aging and with progressing hair loss. J Dermatol Sci. 2007; 45(2):93-103.

6. Barber BI, Kaufman KD, Kozloff RC, Girman CJ, Guess HA. A hair growth questionnaire for use in the evaluation of therapeutic effects in men. J Dermatol Treat. 1998; 9(3):181-6.
7. Iwabuchi T, Ideta R, Ehama R, Yamanishi H, Ino M, Nakazawa Y, et al. Topical adenosine increases the proportion of thick hair in Caucasian men with androgenetic alopecia. J Dermatol. 2016; 43(5):567-70.

8. Ishino A, Takahashi T, Suzuki J, Nakazawa Y, Iwabuchi T, Tajima M. Contribution of hair density and hair diameter to the appearance and progression of androgenetic alopecia in Japanese men. Br J Dermatol. 2014; 171(5):1052-9.

9. Watanabe Y, Nagashima T, Hanzawa N, Ishino A, Nakazawa Y, Ogo $\mathrm{M}$, et al. Topical adenosine increases thick hair ratio in Japanese men with androgenetic alopecia. Int J Cosmet Sci. 2015; 37(6):579-87.

10. Faghihi G, Iraji F, Rajaee Harandi M, Nilforoushzadeh MA, Askari G. Comparison of the efficacy of topical minoxidil 5\% and adenosine $0.75 \%$ solutions on male androgenetic alopecia and measuring patient satisfaction rate. Acta Dermatovenerol Croat. 2013; 21(3):155-9.

11. Ramos PM, Miot HA. Female Pattern Hair Loss: a clinical and pathophysiological review. An Bras Dermatol. 2015; 90(4):529-43.

12. Draelos ZD, Jacobson EL, Kim H, Kim M, Jacobson MK. A pilot study evaluating the efficacy of topically applied niacin derivatives for treatment of female pattern alopecia. J Cosmet Dermatol. 2005; $4(4): 258-61$.

\section{The Acta Medica Philippina is now accepting limited advertising for its front and back cover (colored), as well as for available spaces in some of its pages, as appropriate. For inquiries and submission of proposals, please email us at actamedicaphilippina.upm@up.edu.ph}

